\title{
An Innovative Approach for Gob-Side Entry Retaining by Roof Cutting in Steeply Pitching Seam Longwall Mining with Hard Roof: a Case Study
}

\author{
Li Zhang ${ }^{1,2,3}$ • Jing Zhao ${ }^{2,3}$. Chuanwei Zang ${ }^{4}$. Shuanlin Wang ${ }^{2,3}$
}

Received: 7 December 2019 / Accepted: 14 April 2020 / Published online: 6 May 2020

(C) The Author(s) 2020

\begin{abstract}
The application of gob-side entry retaining (GER) in steeply pitching seam longwall mining with a hard roof has always been a difficult problem. Based on the simplified roof beam mechanical model, the traditional gob-side entry retaining by packing (GERP) roof structure evolution process and its problems with use in steeply pitching seams are analyzed. Therefore, based on the unique characteristics of the gangue rolling and accumulating in the steeply pitching seam, this contribution proposes an innovative method of gob-side entry retaining by roof cutting (GERRC) in steeply pitching seam and details its technical process. The roof structures of the GERRC and the GERP are compared. Taking the Chang Gouyu Coal Mine as a case study, field experiments were carried out. This research finds that the GERRC can both overcome the impact of rolling gangue on roadside support and make the rolling and stacking gangue become a roadside support. The roof structure of the GERRC is in a one-time statically indeterminate state, which is conducive to the stability of the roadway. In the field test, the total displacement of the roadway roof and floor is $97 \mathrm{~mm}$, the supporting pressure of the serried single props is less than $28 \mathrm{MPa}$, and the props have no obvious bending phenomenon.
\end{abstract}

Keywords Steeply pitching seam · Gob-side entry retaining (GER) · Gob-side entry retaining by roof cutting (GERRC) · Structural evolution

\section{Introduction}

Gob-side entry retaining (GER) refers to maintaining either headentry or tailentry behind the working face by constructing a fill-in sidewall on the gob side with special support to be reused for the next panel $[1,2]$. This technology has obvious advantages in improving coal recovery, and reducing roadway development, while solving the problem of gas accumulation

Li Zhang

sdz1777@126.com

1 School of Energy and Mining Engineering, China University of Mining and Technology (Beijing), Beijing 100083, People's Republic of China

2 Safety Branch, China Coal Research Institute, Beijing 100013, People's Republic of China

3 State Key Laboratory of Coal Mining and Clean Utilization (China Coal Research Institute), Beijing 100013, People's Republic of China

4 College of Energy and Mining Engineering, Shandong University of Science and Technology, Qingdao 266510, Shandong, People's Republic of China at the upper corner [3, 4]. According to the different roadside supports, the GER can be divided into the traditional gob-side entry retaining by packing (GERP) and gob-side entry retaining by roof cutting (GERRC). The GERP means that the packed gangue, concrete, or high water material along the edge of the gob is used as roadside support during the process of mining [5-9]. The GERRC entails cutting the roof at the edge of the gob and using the mine pressure for caving and forming the roadway [10].

The GERP has been developed for more than 30 years and has achieved many beneficial results in terms of roadway stability control [11, 12], roof structure movement [13-16], and packing body mechanical properties $[17,18]$. For a steeply pitching seam $\left(35^{\circ} \sim 55^{\circ}\right)$, the natural stop angle of gangue in the gob is less than the coal seam dip angle, and thus, the gangue will naturally roll and accumulate in the lower end of the working face. The falling gangue has a great impact force and often causes personal injury, limiting the application of the GER in a coal seam with a steeply pitching seam [19].

The GERRC is a new technology proposed within the last 5 years. With the popularization and application of the "110 construction method" (meaning that only the first working 
face in the mining area just needs one advanced roadway excavation; the other following working faces do not need advanced roadway excavation by using the GERRC technology) [20], the technology and relevant theories of the GERRC are gradually being developed. M.C. $\mathrm{He}$ and co-workers [21-23] put forward the idea of the GERRC and developed related supporting equipment. Sun et al. [24] studied the key technology of roof cutting in the thin coal seam. Gao et al. [25] analyzed the influence of roof cutting on roof collapse. Wang et al. [26] found that the surrounding rock stress of the GERRC is significantly less than that of the GERP. At present, the GERRC is mainly applied in near-horizontal coal seams and rarely in steeply pitching seams.

Based on the unique characteristics of gangue rolling and accumulating in the gob of steeply pitching seams, this paper proposes an innovative method, the GERRC in steeply pitching seams. A comparative analysis between the GERRC and the traditional GERP shows that the GERRC is not only better than the GERP with regard to the roof structure of the roadway but can also turn the disadvantages of the gangue rolling impact into the advantages of roadside support. The technological process of the GERRC in a steeply pitching seam is described in detail and tested in the Chang Gouyu Coal Mine.

\section{Roof Structure of the GERP and its Limitations in the Steeply Pitching Seam}

\subsection{Hard Roof Breaking Position}

Previous studies [27] have shown that with the advance of the working face, the first weighting of the roof is "O-X" breaking (the broken line of the roof at the edge of the gob is O-shaped inside the gob $\mathrm{X}$-shape, as shown in the red dotted line in Fig. 1a), and the periodic weighting on both ends of the working face forms an arc triangle. When the arc triangular block reaches the limited span and the side support of the roadway does not play an effective supporting role, the arc triangular block is easy to break at the solid coal side. The GERP is under the arc triangle (Fig. 1b).

\subsection{Roof Structural Evolution of the GERP}

The roof structural model of the GERP is shown in Fig. 2. According to the different roof structures of the GERP, the roadway can be divided into three areas: advance area of the working face (area I), arc triangle block unbroken area in the gob (area II), and arc triangle block broken area in the gob (area III). In area I, the roof above the roadway is not broken, and thus, the roof structure is a clamped-clamped beam (Fig. 2(a)). In area II, the roof of the roadway is intact above the coal pillars and broken on the side of the gob, and thus, the roof structure is a long cantilever beam with one side fixed and the other side free (Fig. 2(b)). In area III, the roof is broken on the side of the coal pillar with the weight of the overburden completely borne by the roadside support and the coal pillar, and thus, the roof structure is a simply supported beam (Fig. 2(c)). The longer the cantilever is, the greater the stress that the roadside support needs to bear is, and thus, the worse the roadway stability is. The length of area II can be calculated by Eq. 1 [28]:

$L_{\max }=\frac{\sqrt{2} h}{2} \sqrt{\frac{4 R_{t}}{q \cos \alpha}-\frac{\tan ^{2} \alpha}{3}}$

where $L_{\max }$ is the limited span of the arc triangle block, $\mathrm{m} ; h$ is the thickness of the roof, $\mathrm{m} ; \alpha$ is the dip of the coal seam, ${ }^{\circ} ; q$ is the uniform load of the overburden, MPa; and $R_{t}$ is the tensile strength of the roof, MPa.

\subsection{Limitations of the GERP in a Steeply Pitching Seam}

In the working face of a steeply pitching seam with hard roof, the roof easily produces a large area of suspended roof at the
Fig. 1 Main roof "O-X" breaking pattern: a top view, the A-A line is the vertical section of roof and $\mathbf{b}$ vertical section of roof

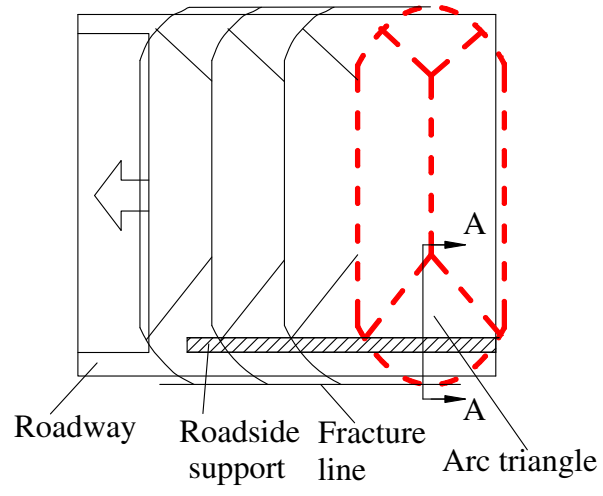

(a)

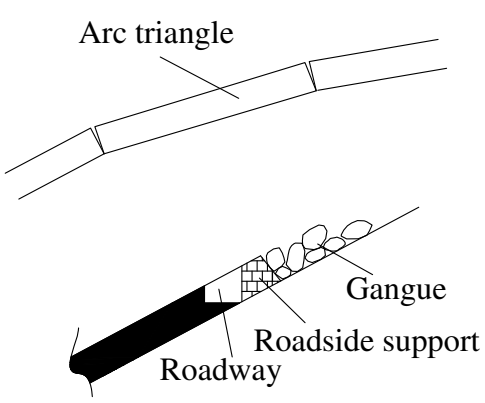

A-A 


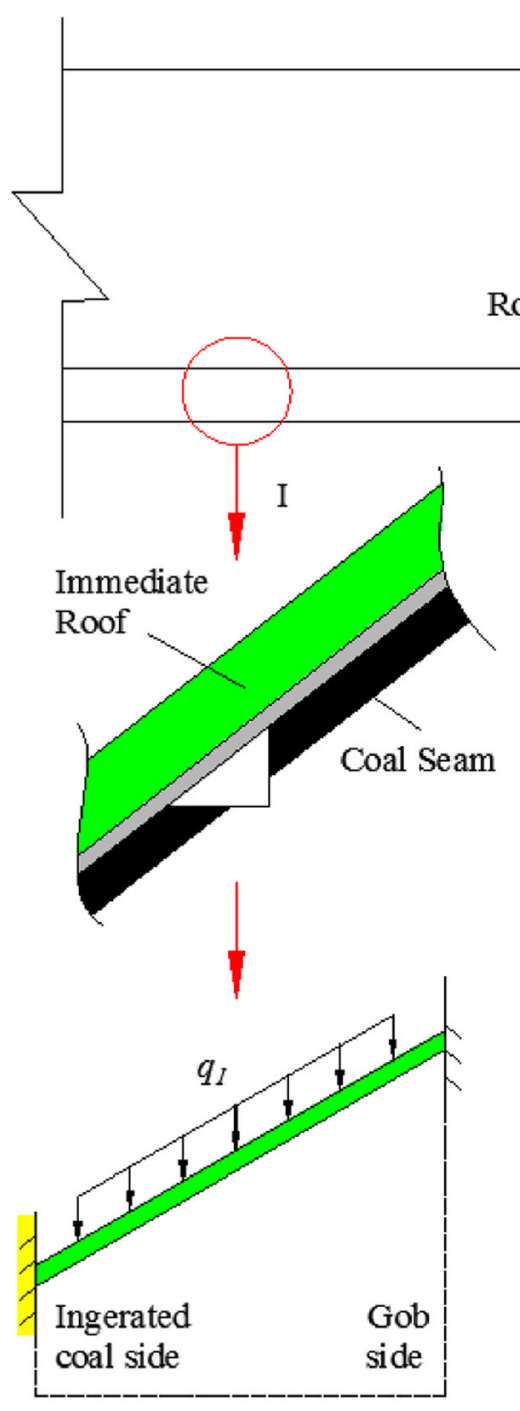

(a)

Coal seam

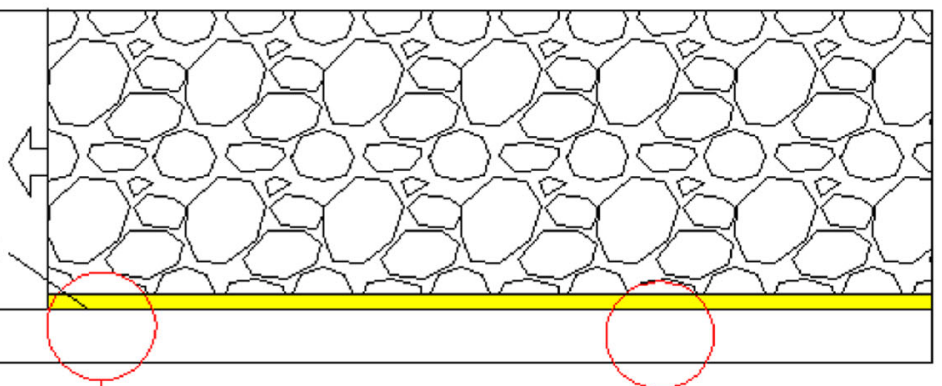

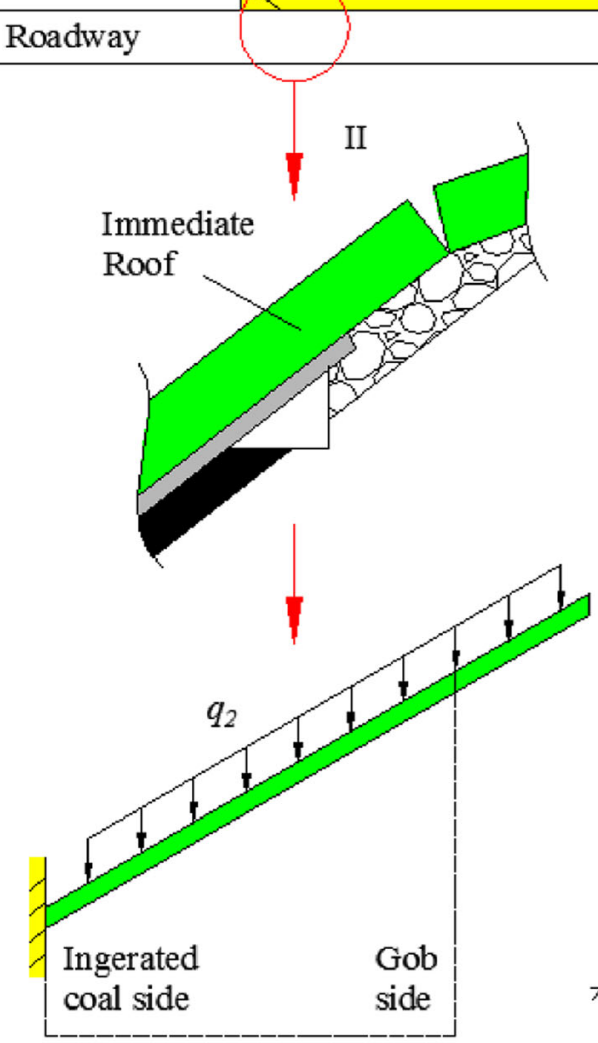

(b)

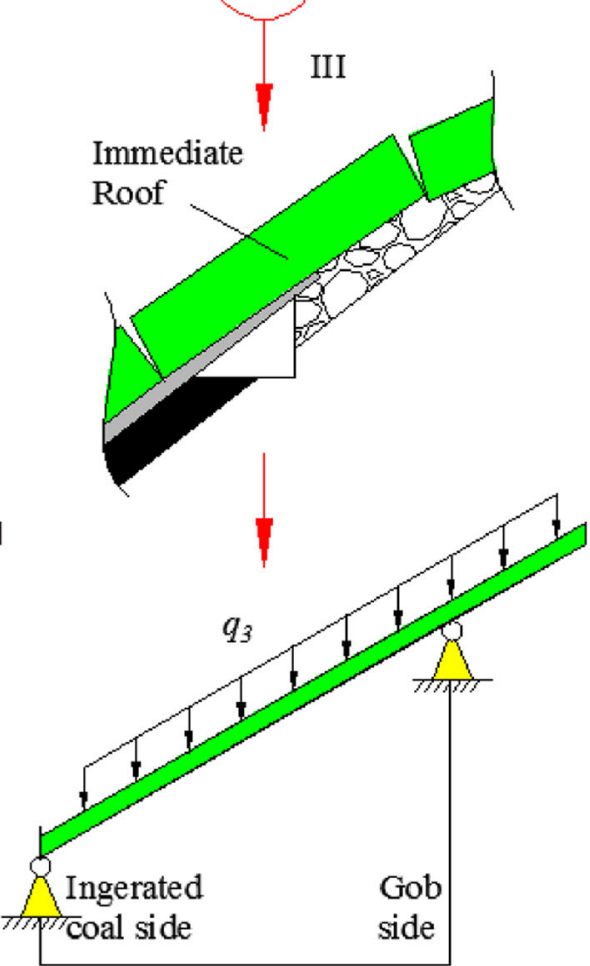

(c)

Fig. 2 The roof structural evolution of the GERP: (a) fixed-end, (b) long cantilever beam, and (c) simply supported beam. $q_{i}(\mathrm{i}=1,2,3)$ is the uniform load of the overlying strata

lower end of the face. The falling gangue is in the middle, and the upper part, of the gob slides and rolls toward the lower part of the working face. After the acceleration of the falling gangue caused by the inclined length of the working face, the supporting structure of the roadway is destroyed by the great impact force. The falling gangue frequently causes accidents and economic loss, which limits the application of GERP in steeply pitching seams. Three gangue rolling accidents happened when the GERP was used in the 1501 working face, including two minor injury accidents and one serious injury accident.

The movement of the falling gangue in the middle and upper parts of the gob can be divided into three stages, i.e., free falling stage, sliding stage, and rolling stage. The impact force of gangue in the rolling stage is the largest, as shown in Fig. 3.

\section{GERRC in Steeply Pitching Seam}

In the working face with hard roof, the area of the suspended roof in the gob is large. The falling gangue in the middle and upper parts of the gob can directly impact the roadside support and rush into the transportation roadway of the working face. How to effectively avoid the impact of falling gangue in the middle and upper parts of the gob on the roadside support is the key to the problem. Based on the analysis of the caving characteristics of the hard roof in the steeply pitching seam and the technology of roof cutting, the method of the GERRC in a steeply pitching seam is put forward. 
Fig. 3 Movement process of falling gangue

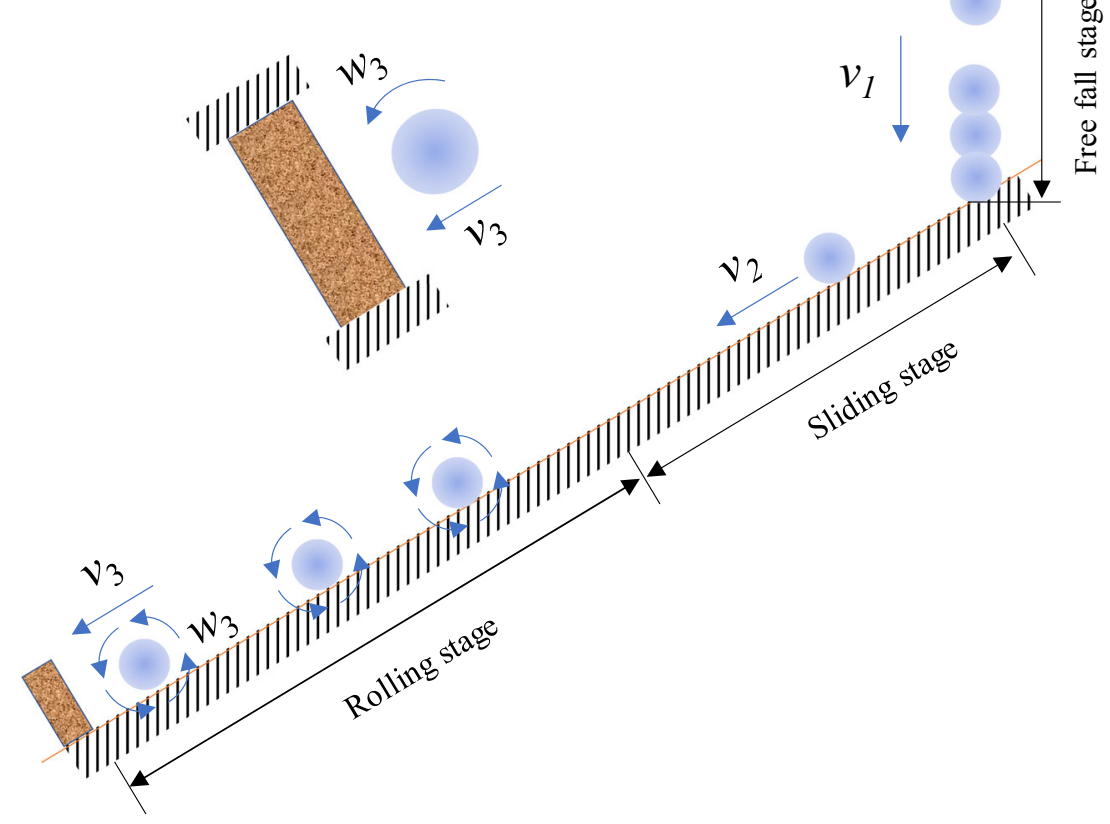

\subsection{Technical Principle of the GERRC}

The hard roof at a certain distance to the front of the working face of the transport roadway is cut so that the hard roof at the lower end of the working face will fall with mining. The falling gangue is close to the roadside support, and in the free falling stage, the impact force on the roadside support is the smallest. The falling gangue piles up in the lower part of the working face under the action of the roadside support and is in a loose state, which buffers the falling gangue in the middle and upper parts of the gob and reduces its impact on the roadside support (Fig. 4a).

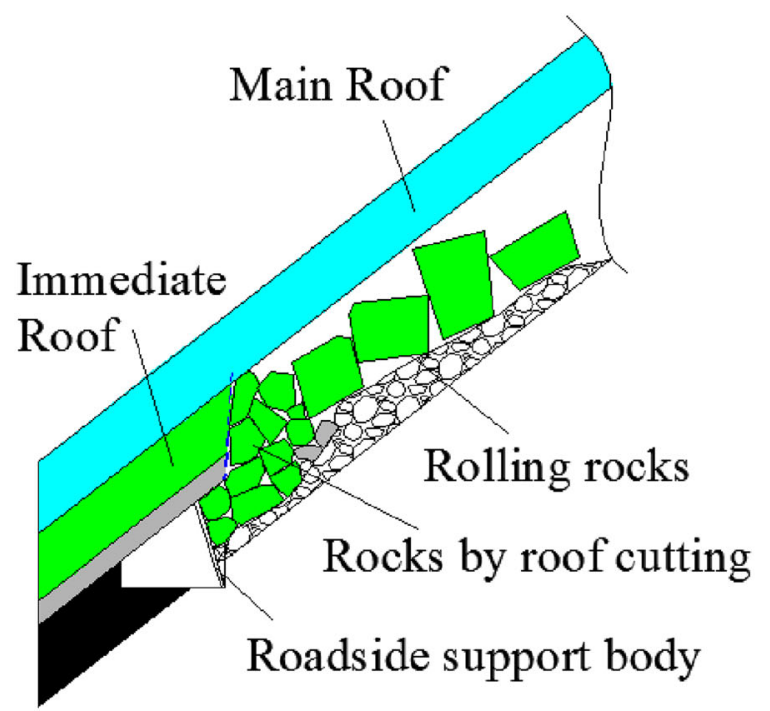

(a)
Under the action of overburden pressure, the lower main roof lags behind the immediate roof fracture along the cutting seam position and compacts the accumulated gangue. The compacted gangue has a certain bearing capacity, which supports the roof together with the roadside support body (Fig. $4 b)$. The accumulated gangue can be easily compressed at the early gangue accumulation stage and has a strong bearing capacity in the later stage, which shows the self-bearing characteristic of "early flexible and later strong" [17]. Ultimately, the rock surrounding the roadway forms a steady-state control system consisting of gangue, a roof beam structure, and a solid coal wall.

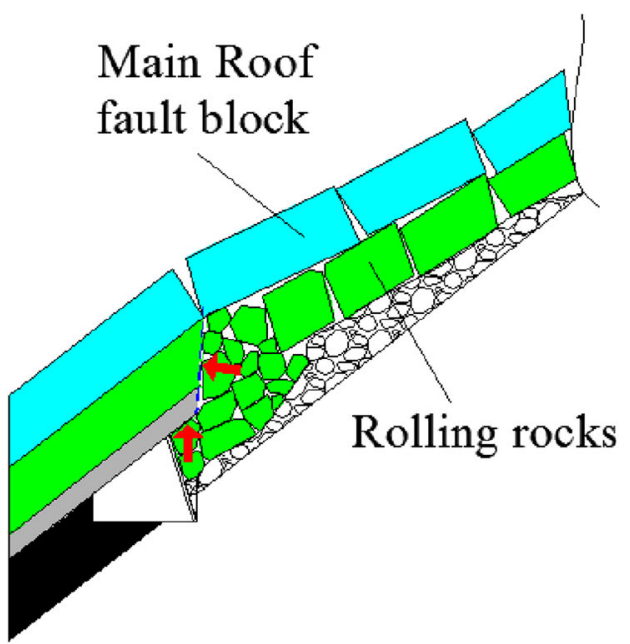

(b)

Fig. 4 Technical principle of the GERRC: a falling gangue piles up and $\mathbf{b}$ it compacts the accumulated gangue 


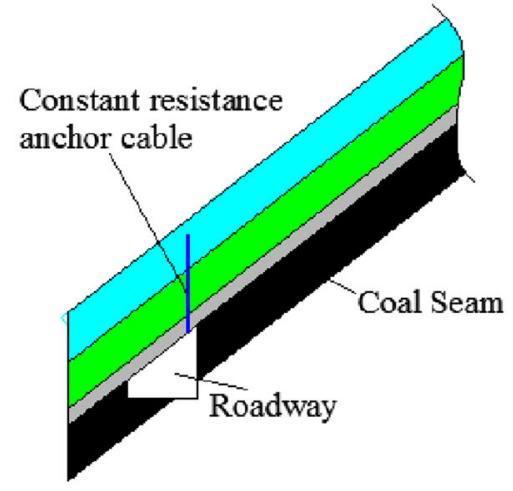

(a)

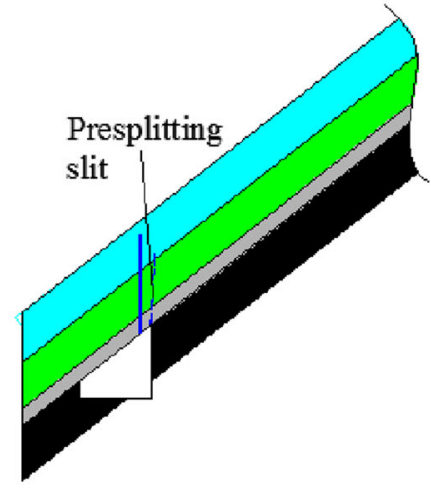

(b)

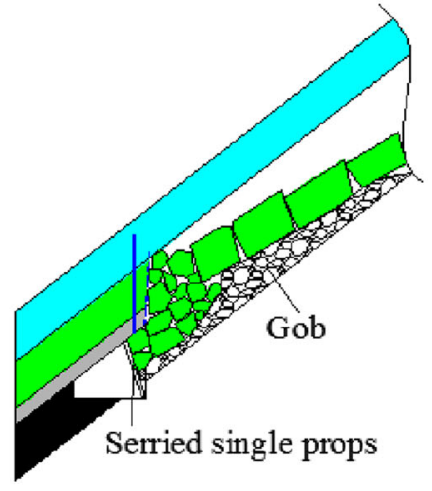

(c)

Fig. 5 The technological process of the GERRC in a steeply pitching seam: a support, $\mathbf{b}$ cutting, and $\mathbf{c}$ protecting

\subsection{Technical Process of the GERRC}

The whole technological process of the GERRC in a steeply pitching seam is shown in the Fig. 5. The technical process of the GERRC is divided into three steps.

First, the support step is described (Fig. 5a). In front of the working face, a row of constant resistance large-deformation anchor cables (CRLAC) is added near the working face to strengthen the roof support. The CRLAC mainly consists of the constant resistance body, steel strand, pallet, and lock set. When the force of the anchor cable is less than the constant resistance value, the steel strand is in an elastic working state. When the force is greater than the constant resistance value, the cone in the constant resistance casing slips along the inner wall of the casing, and at this time, the structural deformation of the constant resistance device is used to resist the applied load until the surrounding rock is stable again. The principles of the CRLAC and constant resistance yield characteristics are shown in Fig. 6 [25]. The maximum working resistance of the CRLAC is $350 \mathrm{kN}$, and the allowable maximum deformation is $400 \mathrm{~mm}$.

Second, the cutting step is described (Fig. 5b). In front of the working face, the blasting borehole is set near the working face, and the charging blasting is carried out to cut off the hard

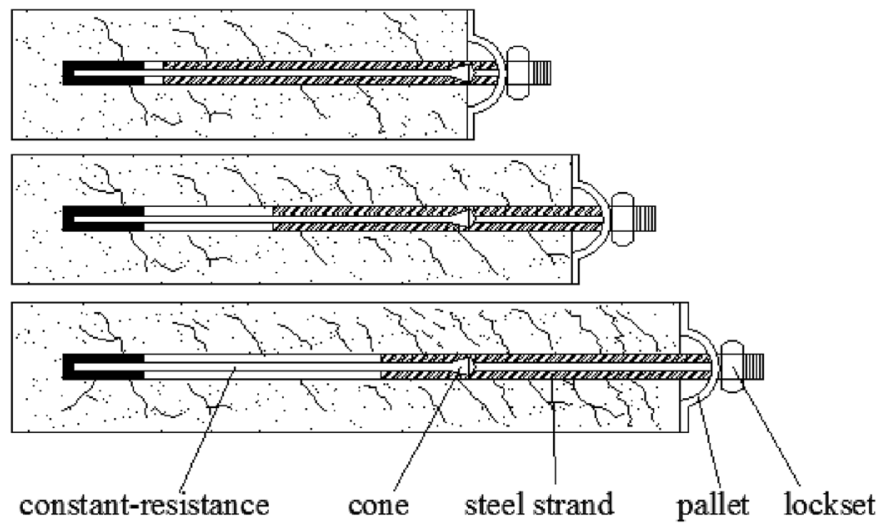

(a) roof. The blasting uses an energy gathering tube (EGT) to form directional cracks after blasting. The height of the roof cutting should be greater than that of the collapsed roof required for filling in the gob and is related to the collapse and height of the rock. The cutting angle should make the rock strata fall directly without forming a hinged structure. The EGT is shown in Fig. 7. The calculation formula of the cutting height is as follows [24]:

$H=\frac{m_{0}}{k-1}$

where $H$ is the cutting height required for filling in the gob, $\mathrm{m}$; $m_{0}$ is the mining height of the coal seam, $\mathrm{m}$; and $k$ is the initial coefficient of bulk increase, generally, 1.25-1.35.

Third, the protecting step is described (Fig. 5c). After the work surface is advanced, the serried single props are used timely behind the working face as a gangue blocking device and roadside strengthening support. The broken gangue rolls down to the lower part of the working face due to gravity, resulting in a lateral impact force. The gangue blocking device resists this lateral deformation. In addition, since the supporting structures concentrate near the slit side, the sinking on the slit side is more obvious than that on the solid

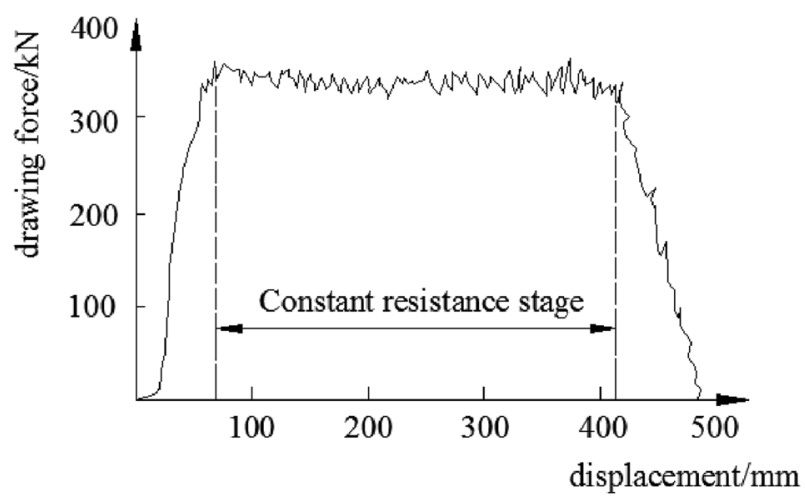

(b)

Fig. 6 CRLAC principle and resistance yield characteristics: a principle of the CRLAC and $\mathbf{b}$ constant resistance yield characteristic curve 


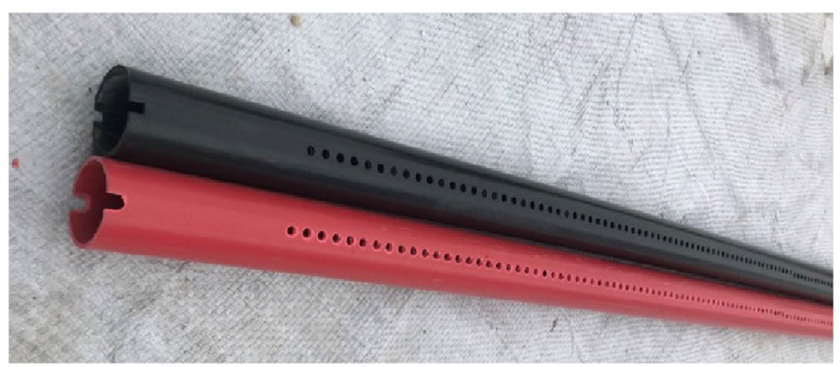

Fig. 7 Energy gathering tube (EGT)

coal side. Therefore, the roadside support undergoes a certain degree of yielding. The working characteristics of the single prop is shown in Fig. 8 [27]. When the force exceeds the working resistance, hydraulic fluid will leak out of the prop, and the length of the prop will shorten. The prop exhibits excellent resistance to constant pressure and bending. The working resistance of those props is $300 \mathrm{kN}$.

\subsection{Roof Structural Evolution of the GREEC}

As shown in Fig. 9, the roof beam successively undergoes four states: clamped-clamped beam, one-time statically indeterminate beam with one side fixed and the other simply supported, short cantilever beam, and one-time statically indeterminate beam with one side fixed and the other simply supported. According to the different connection states between the roadway roof and the both sides of the roadway, the GERRC is divided into four areas: ahead of the working face (area I), roof cutting (area II), dynamic pressure (area III), and pressure stabilization (area IV).

\subsection{Difference Analysis of the Roof Structures Between the GERP and the GERRC}

Unlike the GERP, the roof structure of the GERRC has changed significantly. The roof beam changes from a long cantilever state simply supported on both sides to a short cantilever state with one side fixed and the other simply supported. At this time, the roof beam is in a one-time statically indeterminate state, which is more conducive to the stability of the roadway. According to the structural mechanics, the analysis is performed on the stresses of the simply supported inclined beam and one-time statically indeterminate inclined beam under a uniform load. The stress is shown in Fig. 2(c) and Fig. 9(d). The lengths of the beams in Fig. 2(c) and Fig. $9(\mathrm{~d})$ are $l_{1}$ and $l_{2}$, respectively.

In a simply supported inclined beam, the force of the roadside support is

$R_{A}=\frac{q_{3} l_{1}}{2}$

In a one-time statically indeterminate beam, the force of the roadside support is

$R_{A}{ }^{\prime}=\frac{3 q_{4}{ }^{\prime} l_{2}}{8}$

Assuming that $q_{3}=q_{4}{ }^{\prime \prime}=q$, the stress of roadside support decreases.

$\Delta R_{A}=\frac{4 q l_{1}-3 q l_{2}}{8}$

\section{Case Study}

\subsection{Engineering Background}

This paper takes the 1502 working face of the Chang Gouyu Coal Mine as a case study. The length and width of the 1502 working face are $199 \mathrm{~m}$ and $87 \mathrm{~m}$, respectively (Fig. 10a). Number 15 coal is mined in working face 1502. It is anthracite with a high degree of coalification. It is not easy to self-ignite

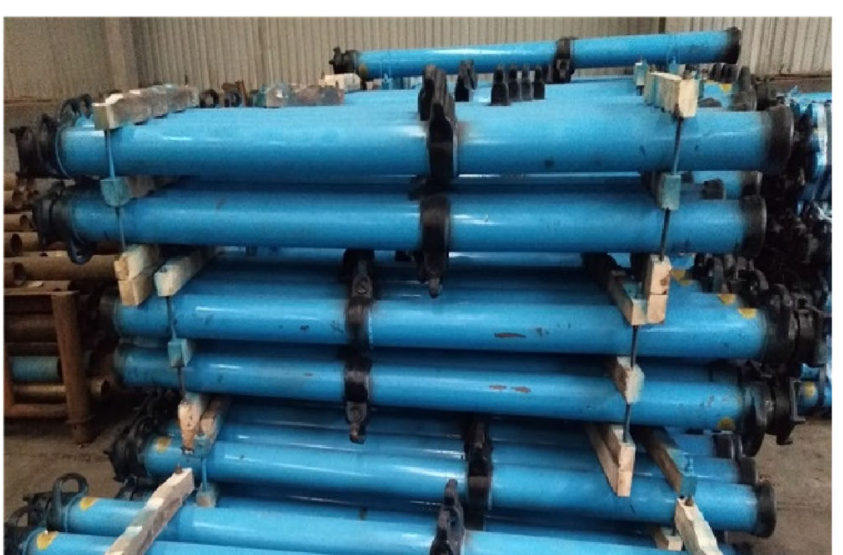

(a)

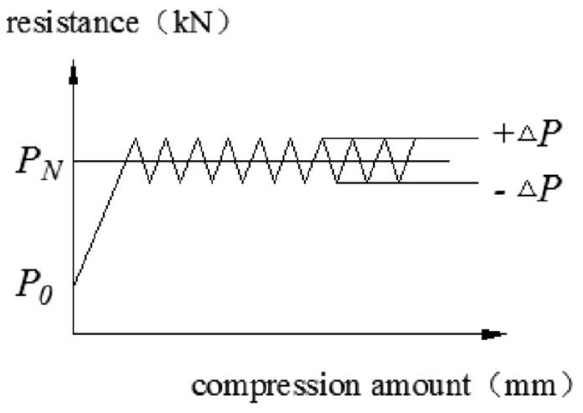

(b)

Fig. 8 Working characteristics of the single hydraulic prop: a single hydraulic prop and $\mathbf{b}$ working characteristics. $P_{\mathrm{N}}$ is the normal working resistance 
with a self-heating temperature of $650^{\circ}$. Coal dust is not explosive. Chang Gouyu Coal mine is low gas mine. The coal seam depth is $880-920 \mathrm{~m}$, with an average thickness of $2.3 \mathrm{~m}$ and an average dip angle of $36^{\circ}$ (Fig. 10b). The first immediate roof is a thin layer of carbonaceous siltstone, which can easily fall. The second immediate roof is a thick siltstone layer without fissure, which is difficult to make fall. The main roof is a breccia layer with a developed joint. The upper 1501 working face was mined in the inclined direction from the upper part to the lower part. The 1502 working face was mined by the method of comprehensive mechanization, with the roof managed by a caving method. The mining drilling histogram of the 1502 working face is shown in Fig. 10c.
The physical and mechanical parameters of the no. 15 coal, roof, and floor rock blocks were obtained in the laboratory. Other rock formation parameters can be referenced from the geological exploration report and the similar rock blocks parameter database in the UDEC manual [29]. According to engineering experience, the parameters of the elastic modulus, cohesion, and tensile strength of the rock mass are $1 / 5$ of the corresponding parameters of the rock blocks, and the Poisson ratio of the rock mass is 1.2 times that of the rock blocks [30]. The calculated physical and mechanical parameters of the rock masses are shown in Table 1.

The original support of the roadway is bolt and anchor cable support. The supporting parameters are shown in Fig.
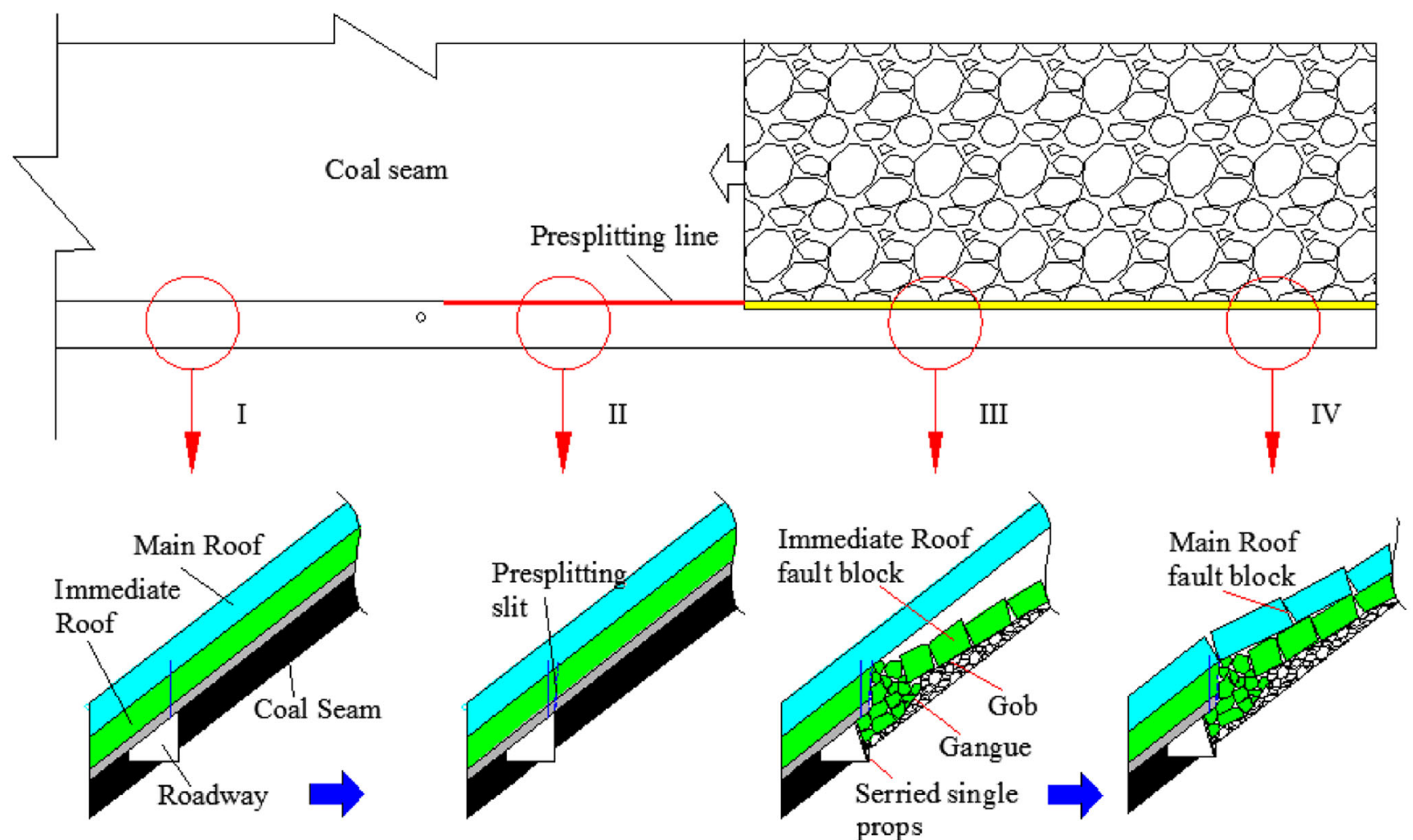

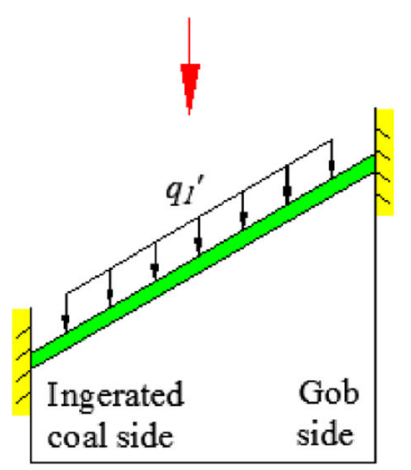

(a)

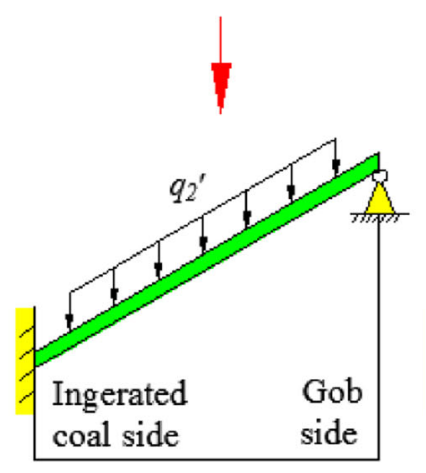

(b)

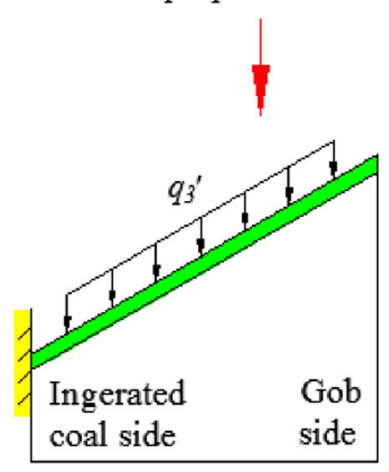

(c)

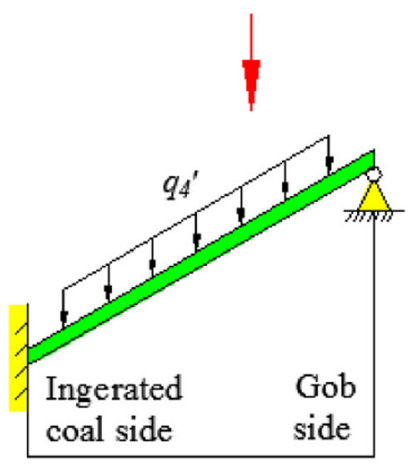

(d)
Fig. 9 Roof structural evolution of the GERRC: (a) fixed-end, (b) onetime statically indeterminate beam with one side fixed and the other simply supported, (c) short cantilever, and (d) one-time statically indeterminate beam with one side fixed and the other simply supported. $q_{i}{ }^{\prime}(i=1,2,3,4)$ is the uniform load of the overlying strata 


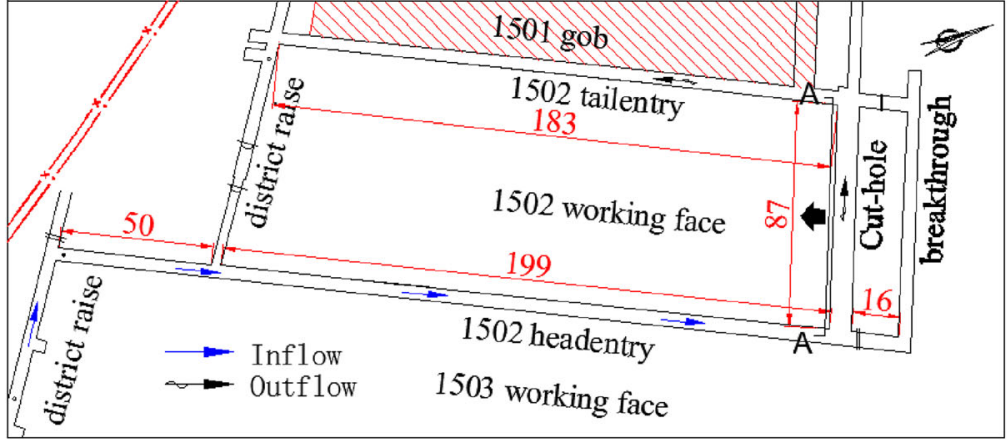

(a)

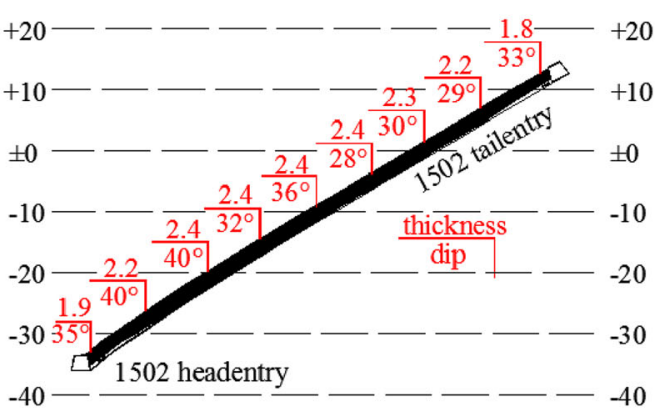

A-A

(b)

\begin{tabular}{|c|c|c|}
\hline Lithology & Column & $\underset{/ \mathrm{m}}{\text { Thickness }}$ \\
\hline Mudstone & & 3.1 \\
\hline Siltstone & & 6.8 \\
\hline Mudstone & & 9.4 \\
\hline Breccia & & 15.2 \\
\hline Siltstone & & 12.6 \\
\hline $\begin{array}{l}\text { Carbonaceous } \\
\text { siltstone }\end{array}$ & & 0.5 \\
\hline 15 Coal & & 2.5 \\
\hline Siltstone & -- & 13.8 \\
\hline Mudstone & & 8.3 \\
\hline
\end{tabular}

(c)

Fig. 10 Basic information of the 1502 working face of the Chang Gouyu Coal Mine: a working face mining engineering plan, $\mathbf{b}$ cut coal seam profile, and $\mathbf{c}$ drilling histogram

11. The spacing and row spacing of roof bolting of the roadway roof are $1000 \mathrm{~mm} \times 1000 \mathrm{~mm}$, and those of the roadside are $1000 \mathrm{~mm} \times 1000 \mathrm{~mm}$. The spacing of the cable is $4000 \mathrm{~mm}$

Table 1 Physical and mechanical parameters of rock masses

\begin{tabular}{|c|c|c|c|c|c|c|c|c|c|c|c|}
\hline \multirow[t]{2}{*}{ Lithology } & \multicolumn{6}{|c|}{ Rock mass properties } & \multicolumn{5}{|c|}{ Contact properties } \\
\hline & $D / \mathrm{kg} \cdot \mathrm{m}^{-3}$ & $\begin{array}{l}K / \\
\mathrm{GPa}\end{array}$ & $\begin{array}{l}G / \\
\mathrm{GPa}\end{array}$ & $\begin{array}{l}\mathrm{Cl} \\
\mathrm{MPa}\end{array}$ & $\begin{array}{l}\varphi l \\
\circ\end{array}$ & $\begin{array}{l}\sigma_{\mathrm{t}} / \\
\mathrm{MPa}\end{array}$ & $\begin{array}{l}k_{\mathrm{n}} / \\
\mathrm{GPa}\end{array}$ & $\begin{array}{l}k_{\mathrm{s}} / \\
\mathrm{GPa}\end{array}$ & $\begin{array}{l}C_{\mathrm{j}} / \\
\mathrm{MPa}\end{array}$ & $\begin{array}{l}\varphi_{\mathrm{j}} / \\
\circ\end{array}$ & $\sigma_{\mathrm{tj}} / \mathrm{MPa}$ \\
\hline 15 Coal & 1360 & 2.0 & 1.0 & 1.6 & 15 & 0.2 & 0.8 & 0.4 & 0 & 10 & 0 \\
\hline Mudstone & 2300 & 3.0 & 1.0 & 2.0 & 20 & 0.1 & 0.6 & 0.3 & 0 & 10 & 0 \\
\hline Breccia & 2900 & 21.4 & 11.0 & 5.6 & 37 & 5.14 & 15.4 & 10.3 & 0 & 15 & 0 \\
\hline Carbonaceous siltstone & 2400 & 10.2 & 4.7 & 6.8 & 42 & 4.21 & 9.2 & 8.4 & 0 & 10 & 0 \\
\hline Siltstone & 2600 & 12.0 & 7.0 & 3.0 & 40 & 1.7 & 11.0 & 10.0 & 0 & 30 & 0 \\
\hline
\end{tabular}

$D=$ density, $K=$ bulk modulus, $G=$ shear modulus, $C=$ cohesion, $\varphi=$ friction angle, $\sigma_{t}=$ tensile strength, $k_{n}=$ normal stiffness, $k_{s}=$ shear stiffness, $C_{j}=$ contact cohesion, $\varphi_{j}=$ contact friction angle, $\sigma_{t j}=$ contact tensile strength 


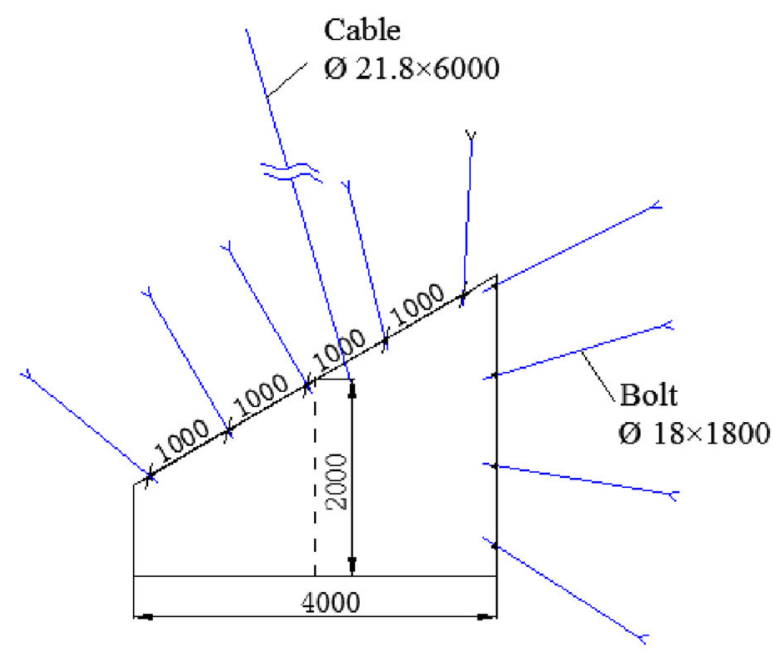

(a)

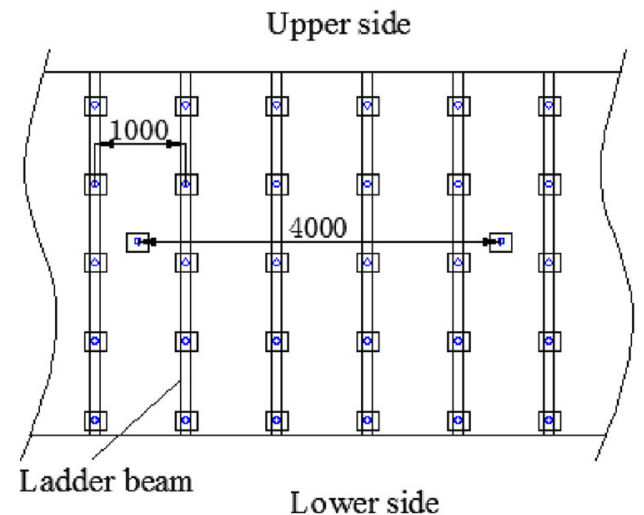

(b)

Fig. 11 Original support of the roadway: a cross-section diagram and $\mathbf{b}$ top view

Since the immediate roof is a thick and hard siltstone layer, the gob is prone to form a large area suspended roof. In the GERP of the 1501 working face, the rockfall in the middle and upper parts of the gob has a great impact on the side support of the roadway, and the bending rate of the serried single props reaches $58.3 \%$.

\subsection{Optimization of the Roof Cutting Angle}

When the rock collapses due to cutting, the rock mass easily forms a hinge structure, especially in steeply pitching seams. Therefore, the optimization of the cutting angle is very important. In general, when cutting is vertical to the roadway roof, the scope of dangling is the smallest. However, the dynamic shear is easily generated in the process of gangue collapse, hindering the rock from falling. As the cutting angle increases, the contact area between the bulging gangue and the roof increases, and the support force of the roof is enhanced. This response increases the hanging range of the roof beam and has a negative effect on the entry being retained. A reasonable cutting angle is not only conducive to the roof falling in the gob but also optimizes the surrounding rock stress.

Based on the occurrence condition of the coal seam in the 1502 working face, the numerical simulations of surrounding rock stress with three cutting angles, perpendicular to the roof (dip angle of $127^{\circ}$ ), vertical (dip angle of $90^{\circ}$ ), and inclined to the gob direction (dip angle of $60^{\circ}$ ), are carried out by using the software UDEC 4.0. The initial model size is $120 \mathrm{~m} \times$ $70 \mathrm{~m}$. A fixed boundary is used on both sides and the bottom of the model. The vertical stress of $21 \mathrm{MPa}$ is applied to the

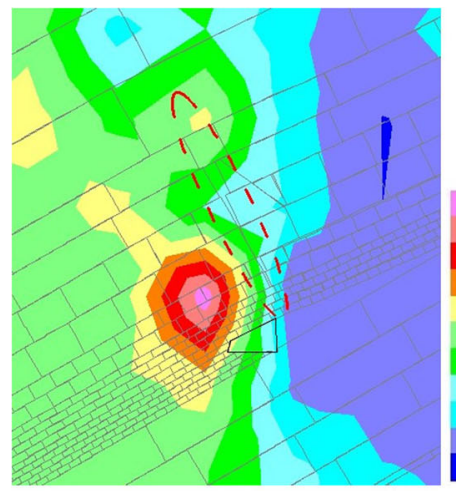

(a)

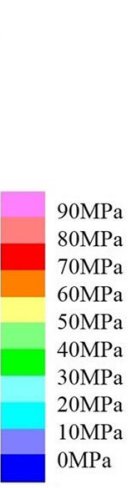

$\mathrm{MPa}$

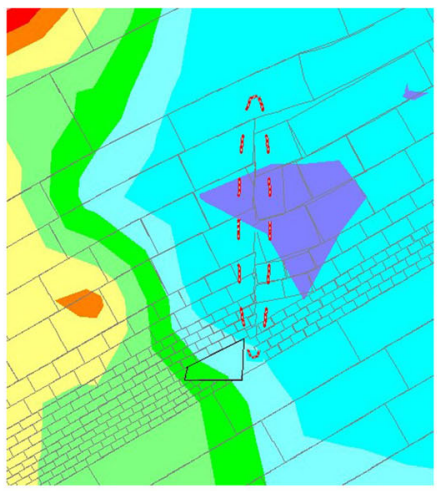

(b)

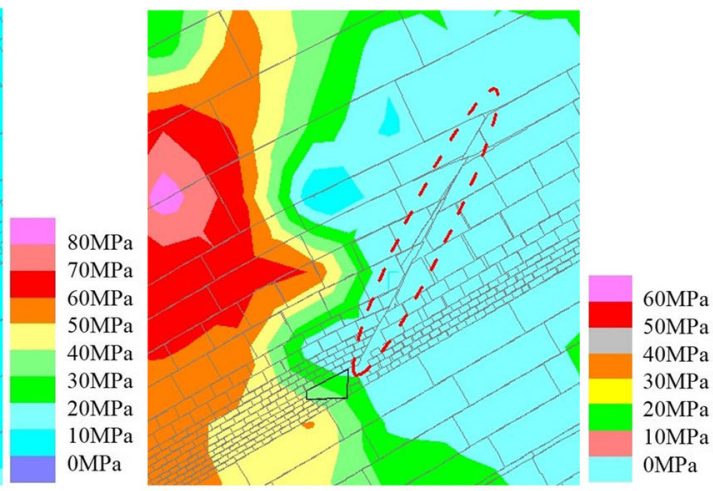

(c)

Fig. 12 Surrounding rock stress distribution with three cutting angles: a perpendicular to the roof (dip angle of $127^{\circ}$ ), b vertical (dip angle of $90^{\circ}$ ), and $\mathbf{c}$ inclined to the gob direction (dip angle of $60^{\circ}$ ) 

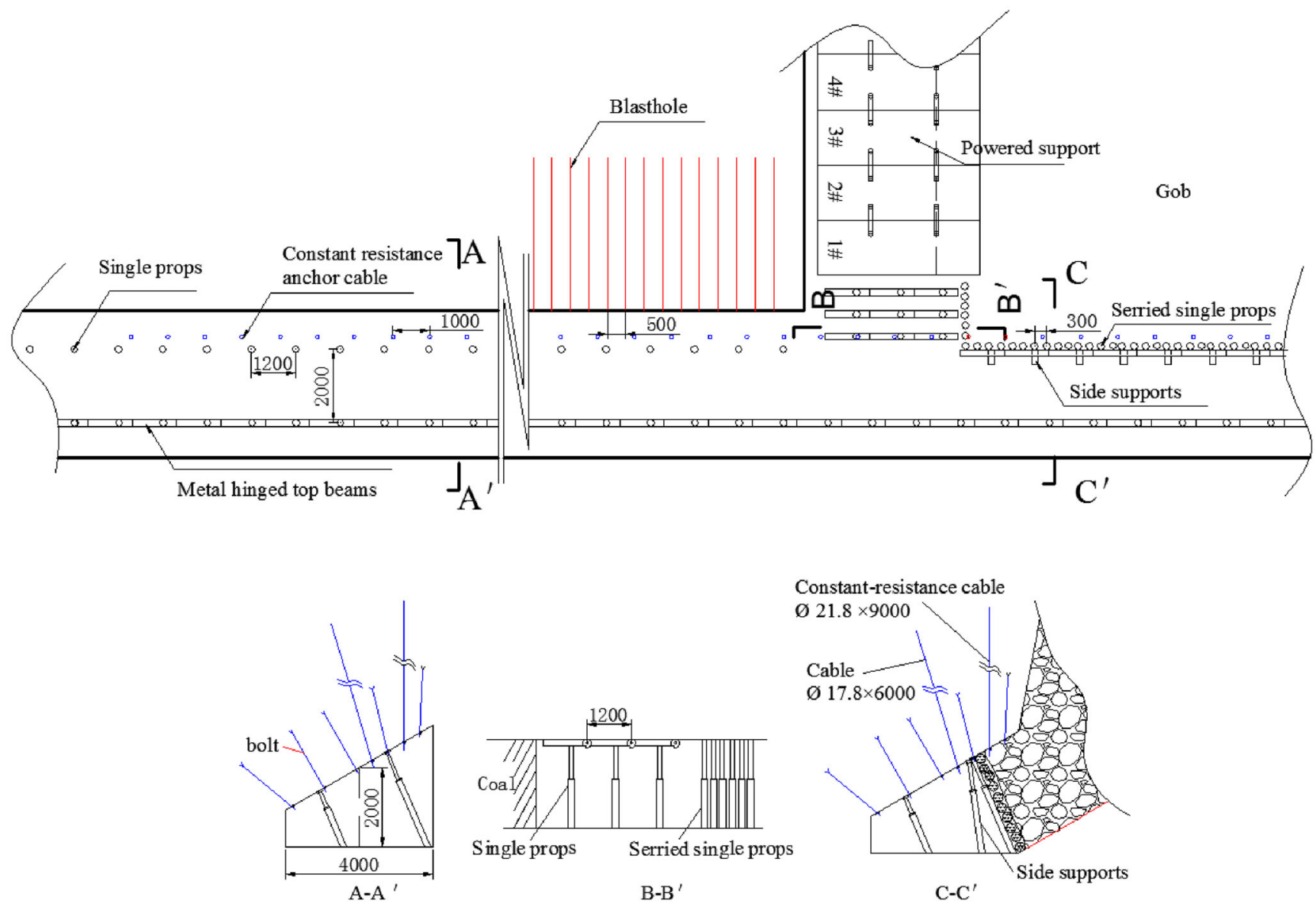

Fig. 13 Support design of the GERRC

upper part (overburden gravity). It is found that when the cutting angle is $127^{\circ}$ or $90^{\circ}$, the hinged structure is formed, which is not conducive to roof collapse
(Fig. 12a, b); when the cutting angle is $60^{\circ}$, the roof is completely collapsed, and the roadside support resistance is less than $20 \mathrm{MPa}$ (Fig. 12c).

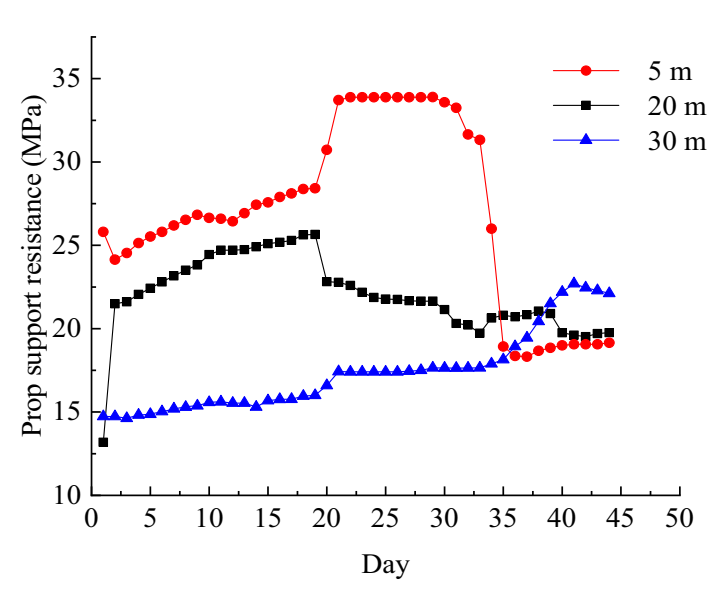

(a)

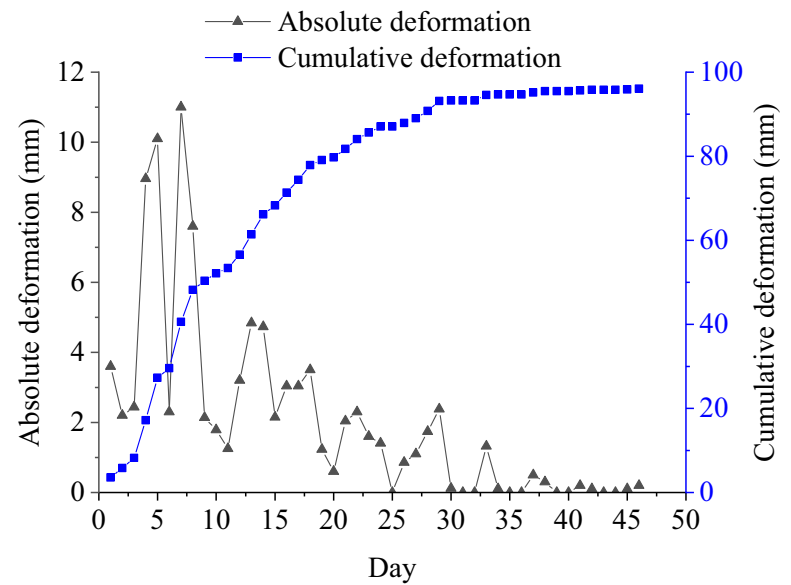

(b)

Fig. 14 Monitoring of the prop support resistance and the deformation of the surrounding rock: a prop support resistance and $\mathbf{b}$ roof-to-floor convergence 


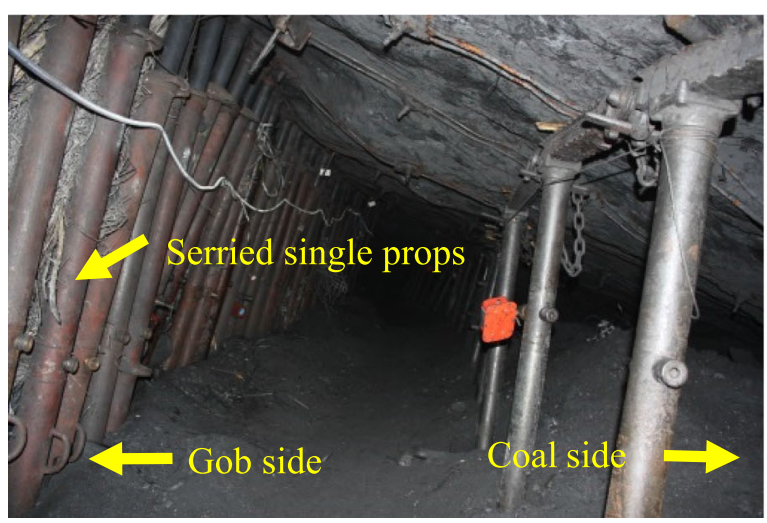

(a)

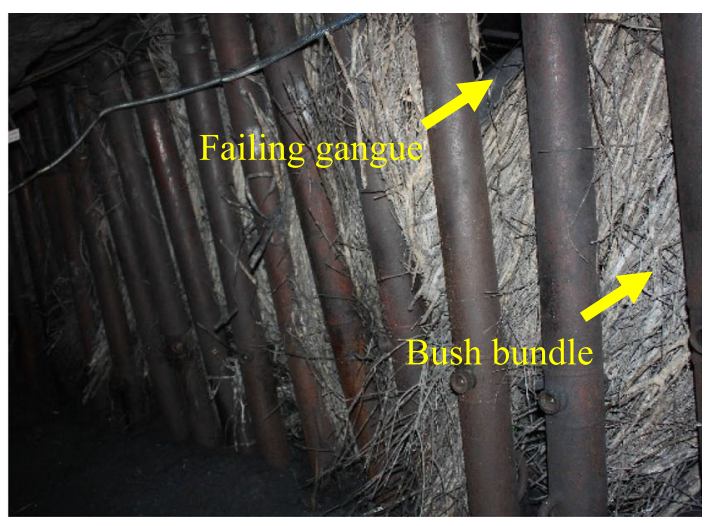

(b)

Fig. 15 GERC effects on the field application: a serried single props and $\mathbf{b}$ bush bundle and failing gangue

\subsection{Parameter Settings}

According to the engineering geological conditions of the 1502 working face and the requirements of roadway surrounding rock control, the relative parameters are set as follows (Fig. 13):

\section{(1) Advanced support in headentry}

Before cutting the roof, two rows of single props are added to strengthen the support at $30 \mathrm{~m}$ in front of the 1502 working face. The spacing and row spacing are $500 \mathrm{~mm} \times 2000 \mathrm{~mm}$. The upper side of the roadway is supported by single props and column caps, and the lower side is supported by single props and metal hinged top beams. A CRLAC is added between the two rows of bolts in the upper part of the roadway, and the CRLAC spacing is $1 \mathrm{~m}$.

\section{(2) Blasting roof cutting}

Roadway roof cutting adopts cumulative blasting. The charge method is hole bottom uncoupling continuous charge. The blasthole depth is $20 \mathrm{~m}$ with a cutting angle of $60^{\circ}$ and a spacing of $0.5 \mathrm{~m}$. The charge length is $18 \mathrm{~m}$, and the sealing length $2 \mathrm{~m}$. The cutting area is at $20 \mathrm{~m}$ in front of the working face.

\section{(3) Roadside support}

Behind the powered support, the roadside of the GERRC is supported by serried single props with a column spacing of $0.3 \mathrm{~m}$. To maintain the stability of serried single props and prevent them from being overwhelmed by gangue, the side supports, within $30 \mathrm{~m}$ behind the powered support, are added on the inside of the serried single props with a spacing of $2 \mathrm{~m}$. The bush bundle is fixed on the outside of the serried single props, which buffers the gangue from slipping into the roadway. After the deformation of the roadway is stable, the side supports could be removed.

\subsection{Analysis of the Effect of the GERRC}

Three measurement points are arranged on the serried single props behind the 1502 working face to monitor the roadway pressure of the GERRC. These three measurement points are respectively arranged at $5 \mathrm{~m}, 20 \mathrm{~m}$, and $30 \mathrm{~m}$ behind the working face. The support resistances of the serried single props are monitored in the mining process of the 1502 working face and shown in Fig. 14a. The KY-82 roof dynamic instrument is arranged at $5 \mathrm{~m}$ behind the working face to monitor the deformation of the roadway with time in the advancing process of the working face.

The absolute roof-to-floor convergence is relatively large in the initial stage of GERRC and becomes stable later (Fig. 14b). The cumulative deformation of the roadway during the entire process of GERRC is $97 \mathrm{~mm}$, which is small. The prop support resistances at these three measurement points range from 18 to $28 \mathrm{MPa}$ during the observation period. Measurement point $1(5 \mathrm{~m})$ is in the dynamic pressure zone during GERRC. During the advancement of the 1502 working face, the support resistance of the prop increases abruptly on the 20th day, and the prop is in the stage of constant resistance and allowable displacement until the gangue exerts its effective bearing capacity. Measurement point $3(30 \mathrm{~m})$ is in the pressure stabilization zone, and the prop support resistance is basically maintained between 16 and $23 \mathrm{MPa}$. The actual application effect of GERRC is shown in Fig. 15.

\section{Conclusions}

(1) The movement process of the gangue in the gob of a steeply pitching seam is divided into three stages: free falling stage, sliding stage, and rolling stage. When the roof is hard, the roof in the lower part of the gob cannot 
easily fall, and the gangue in the middle and upper parts of the gob has a great impact on the side support of the roadway. By using the GERRC method, the roof in the lower part of the gob will fall with mining. The falling gangue in the lower part has little impact on the roadside support. It buffers the falling gangue in the middle and upper parts and supports the roof after compaction.

(2) The roof structure of the GERRC is in a one-time statically indeterminate state with one side fixed support and the other simply support, which is more conducive to the stability of the roadway than the traditional GERP.

(3) Taking the 1502 working face of the Chang Gouyu Coal Mine as a case study, after 50 days of observation, we found that the total deformation of the roadway is $97 \mathrm{~mm}$, the support resistances of the three measurement points behind the working face are in the range of $18 \sim 28 \mathrm{MPa}$, the single hydraulic prop does not show obvious bending and breaking phenomenon, and the size of the GERRC fulfills the requirements of mine ventilation and transportation.

Funding Information This study was supported by the National Natural Science Foundation of China (NSFC-51604154).

Data Availability The data used to support the findings of this study are available from the corresponding author upon request.

\section{Compliance with Ethical Standards}

Conflict of Interest The authors declare that they have no conflict of interest.

Open Access This article is licensed under a Creative Commons Attribution 4.0 International License, which permits use, sharing, adaptation, distribution and reproduction in any medium or format, as long as you give appropriate credit to the original author(s) and the source, provide a link to the Creative Commons licence, and indicate if changes were made. The images or other third party material in this article are included in the article's Creative Commons licence, unless indicated otherwise in a credit line to the material. If material is not included in the article's Creative Commons licence and your intended use is not permitted by statutory regulation or exceeds the permitted use, you will need to obtain permission directly from the copyright holder. To view a copy of this licence, visit http://creativecommons.org/licenses/by/4.0/.

\section{References}

1. Yang HY, Cao SG, Wang SQ, Fan YC, Wang S, Chen XZ (2016) Adaptation assessment of gob-side entry retaining based on geological factors. Eng Geol 209:43-151. https://doi.org/10.1016/j. enggeo.2016.05.016

2. Han CL, Zhang N, Xue JH, Kan JG, Zhao YM (2019) Multiple and long-term disturbance of gob-side entry retaining by grouped roof collapse and an innovative adaptive technology. Rock Mech Rock Eng 52(8):1-13. https://doi.org/10.1007/s00603-018-1612-0

3. Bai JB, Shen WL, Guo GL, Wang XY, Yang Y (2015) Roof deformation, failure characteristics, and preventive techniques of gobside entry driving heading adjacent to the advancing working face. Rock Mech Rock Eng 48(6):2447-2458. https://doi.org/10.1007/ s00603-015-0713-2

4. Li YF, Hua XZ (2012) Mechanical analysis of stability of key blocks of overlying strata for gob-side entry retaining and calculating width of roadside backfill. Rock Soil Mech 33:1134-1140

5. Su H, Bai JB, Yan S, Chen Y, Zhang ZZ (2015) Study on gob-side entry retaining in fully-mechanized longwall with top-coal caving and its application. Int J Min Sci Technol 25(2):503-510. https:// doi.org/10.1016/j.ijmst.2015.03.027

6. Cao SG, Zhang S, Li GD, Ran C (2016) Experimental study on the bearing properties of granular gangue. Chin J Undergr Space Eng 12(5):1164-1171

7. Kang HP, Niu DL, Zhang Z, Lin J, Li ZH, Fan MJ (2010) Deformation characteristics of surrounding rock and supporting technology of gob-side entry retaining in deep coal mine. Chin J Rock Mech Eng 29(10):1977-1987

8. Han CL, Zhang N, Li BY, Si GY, Zheng XG (2015) Pressure relief and structure stability mechanism of hard roof for gob-side entry retaining. J Cent S Univ Technol 22:4445-4455. https://doi.org/10. 1007/s11771-015-2992-x

9. Zhang JX, Jiang HQ, Miao XX (2013) The rational width of the support body of gob-side entry in fully mechanized backfill mining. J Min Saf Eng 30(2):159-164

10. Tan YL, Yu FH, Ning JG, Zhao TB (2015) Design and construction of entry retaining wall along a gob side under hard roof stratum. Int J Rock Mech Min Sci 77:115-121. https://doi.org/10.1016/j. ijrmms.2015.03.025

11. Yang JX, Liu CY, Yang PJ, Yang Y (2014) Research on roadside packing technology for end zone of steep inclined coal seam face. Rock Soil Mech 35(2):543-550 http://ytlx.whrsm.ac.cn/CN/ Y2014/V299/I2/543

12. Deng YH, Wang SQ (2014) Feasibility analysis of gob-side entry retaining on a working face in a steep coal seam. Int J Min Sci Technol 24:499-503. https://doi.org/10.1016/j.ijmst.2014.05.013

13. Hua XZ, Lu XY, Li YF (2013) Prevention and control technology of floor heave in gob-side entry retaining with large section of deep mine. Coal Sci Technol 41(9):100-104

14. Feng XW, Zhang N (2015) Position-optimization on retained entry and backfilling wall in gob-side entry retaining techniques. Int $\mathrm{J}$ Min Sci Technol 2(3):186-195. https://doi.org/10.1007/s40789015-0077-y

15. Guo PF, He MC, Wang J, Zhou HT (2017) Test study on multi tray bolt in gob-side entry retaining formed by roof cut and pressure releasing. Geotech Geol Eng 35:1-10. https://doi.org/10.1007/ s10706-017-0253-5

16. Zhou N, Zhang JX, Yan H, Li M (2017) Deformation behavior of hard roofs in solid backfill coal mining using physical models. Energies 10(4):557-577. https://doi.org/10.3390/en10040557

17. Fan DY, Liu XS, Tan YL, Yan L, Song SL, Ning JG (2019) An innovative approach for gob-side entry retaining in deep coal mines: a case study. Energy Sci Eng 7(6):2321-2335. https://doi.org/10. 1002/ese3.431

18. Sun Q, Zhang JX, Huang YL, Wei Y (2019) Failure mechanism and deformation characteristics of gob-side entry retaining in solid backfill mining: a case study. Nat Resour Res 28(113):1-15. https://doi.org/10.1007/s11053-019-09584-4

19. Wu YP, Liu KZ, Yuan DF, Xie PS, Wang HW (2014) Research progress on the safe and efficient mining technology of steeply dipping seam. J China Coal Soc 39(8):1611-1618

20. He MC, Zhu GL, Guo ZB (2015) Longwall mining "cutting cantilever beam theory" and 110 mining method in China - the third 
mining science innovation. J Rock Mech Geotech Eng 7(5):483492. https://doi.org/10.1016/j.jrmge.2015.07.002

21. Wang Q, He MC, Yang J, Gao HK, Jiang B, Yu HC (2018) Study of a no-pillar mining technique with automatically formed gob-side entry retaining for longwall mining in coal mines. Int $\mathrm{J}$ Rock Mech Min Sci 10:1-8. https://doi.org/10.1016/j.ijrmms.2018.07. 005

22. He MC, Gao YB, Yang J, Wang JW, Wang YJ, Zhu Z (2018) Engineering experimentation of gob-side entry retaining formed by roof cutting and pressure release in a thick-seam fast-extracted mining face. Rock Soil Mech 39(1):254-264

23. He MC, Gao YB, Yang J, Gong WL (2017) An innovative approach for gob-side entry retaining in thick coal seam longwall mining. Energies 10(11):1785-1807. https://doi.org/10.3390/ en10111785

24. Sun XM, Liu X, Liang GF, Wang D, Jiang YL (2014) Key parameters of gob-side entry retaining formed by roof cut and pressure releasing in thin coal seams. Chin J Rock Mech Eng 33(7):14491456

25. Gao YB, Yang J, He MC, Wang YJ, Gao Q (2017) Mechanism and control techniques for gangue rib deformations in gob-side entry retaining formed by roof fracturing in thick coal seams. Chin J Rock Mech Eng 36(10):2492-2502
26. Wang YJ, Gao YB, Wang EY, He MC, Yang J (2018) Roof deformation characteristics and preventive techniques using a novel nonpillar mining method of gob-side entry retaining by roof cutting. Energies 11(3):627-644. https://doi.org/10.3390/en11030627

27. Xie SR, Xu L, Zhang GC, Li SJ, Gong S, Yang LG (2015) Subsidence broken of deep gob-side entry retaining surrounding rock structure with large mining height and its control. Rock Soil Mech 36(2):569-575

28. He TJ (2000) The breaking place prediction of face end main roof flap top in the gob-side entry retaining. J China Coal Soc 21(1):2831

29. Itasca Consulting Group, Inc. (2004) UDEC-Universal distinct element code, Version 4.0 Manual. Itasca Consulting Group, Inc., Minneapolis

30. Chen XX, Zhang WB, Jing SG, Wei WZ (2006) Determination of mechanics parameters of mining induced rock mass for numerical simulation. J Min Saf Eng 23(3):341-345

Publisher's Note Springer Nature remains neutral with regard to jurisdictional claims in published maps and institutional affiliations. 